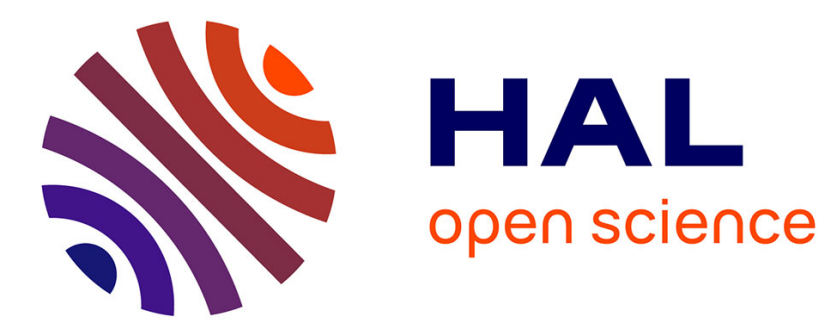

\title{
Are environmental conditions recorded by the organic matrices associated with precipitated calcium carbonate in cyanobacterial microbialites?
}

Pascale Gautret, Rutger de Wit, Gilbert Camoin, S. Golubic

\section{- To cite this version:}

Pascale Gautret, Rutger de Wit, Gilbert Camoin, S. Golubic. Are environmental conditions recorded by the organic matrices associated with precipitated calcium carbonate in cyanobacterial microbialites?. Geobiology, 2006, 4 (2), pp.93-107. 10.1111/j.1472-4669.2006.00073.x . hal-00074240

HAL Id: hal-00074240

https://hal-insu.archives-ouvertes.fr/hal-00074240

Submitted on 9 Jul 2012

HAL is a multi-disciplinary open access archive for the deposit and dissemination of scientific research documents, whether they are published or not. The documents may come from teaching and research institutions in France or abroad, or from public or private research centers.
L'archive ouverte pluridisciplinaire HAL, est destinée au dépôt et à la diffusion de documents scientifiques de niveau recherche, publiés ou non, émanant des établissements d'enseignement et de recherche français ou étrangers, des laboratoires publics ou privés. 


\title{
Are environmental conditions recorded by the organic matrices associated with precipitated calcium carbonate in cyanobacterial microbialites?
}

P. GAUTRET ${ }^{1}$, R. DE WIT ${ }^{2}$, G. CAMOIN ${ }^{3}$ AND S. GOLUBIC $^{4}$

${ }^{1}$ Institut des Sciences de la Terre d'Orléans (ISTO), UMR 6113 du CNRS, Université d'Orléans, Bâtiment Géosciences, F-45067 Orléans Cedex 2, France

${ }^{2}$ UMR 5119 du CNRS \& Université Montpellier II "Ecosystèmes lagunaires" Université Montpellier II, Case 093, Place Eugène Bataillon, F-34095 Montpellier Cedex 05, France

${ }^{3}$ CEREGE, UMR 6635 du CNRS, Europole Méditerranéen de l'Arbois, B.P. 80, F-13545 Aix-enProvence Cedex 4, France

${ }^{4}$ Biological Science Center, Boston University, 5 Cummington Street, Boston, Massachusets 02215, USA

Corresponding author: P. GAUTRET. Tel: (33) 2384946 89; fax: (33) 2384173 08; email: gautret@cnrs-orleans.fr

Running title: Organic matrices of cyanobacterial microbialites

\begin{abstract}
The amino acid composition of organic matrices associated with calcium carbonate precipitates in microbialites built by different Phormidium species (cyanobacteria) have been compared for samples recovered in lagoonal settings from two regions of the Southern Tropical Pacific separated by more than $4000 \mathrm{~km}$ : New Caledonia (Nouméa lagoon) and French Polynesia (Tikehau atoll). Calcium carbonate precipitation in these microbial structures was observed mainly in the interior of the domes and clearly separated from the photosynthetically active surface layer. This study focuses on the
\end{abstract}


hydrolysable amino acid composition of the associated organic matrices that are typically rich in cysteine, leucine, alanine and arginine in New Caledonia, whereas they are particularly rich in dicarboxylic amino acids in French Polynesia. This striking difference is seemingly related to different environmental conditions that characterize the two reef settings. The high cysteine content suggests an origin from metallothioneins produced by the cyanobacteria and/or by epiphytic diatoms that were observed on the toplayer, as the result of the input of metals from terrestrial origin in the Nouméa lagoon. In addition, we analyzed the bulk organic matter of the photosynthetically active surface layer and of the interior of the domes. The former showed remarkable variations of amino acid composition throughout the year 2001, which may potentially reflect the impact of climatological events (e.g. cyclones) and/or a much stronger seasonality in New Caledonia than in French Polynesia. Although the mechanisms behind the differences remain elusive, our study clearly shows that environmental conditions can be reflected by amino acid compositions, particularly for the organic matrices associated with carbonate precipitates.

\section{INTRODUCTION}

Dome-shaped microbialites growing in tropical lagoons constitute an attractive model to study biogenic calcium carbonate crystallization patterns (Sprachta et al., 2001; Gautret et al., 2004). These microbialites are formed by monospecific cyanobacterial colonies, frequently Phormidium species (Sprachta et al., 2001; Abed et al., 2003a, 2003b; Gautret et al., 2004; Pringault et al., 2005). Growth usually starts from a point source from which they expand upward and outward in all directions. This phenomenon has been described by Abed et al. (2003b) as a localized short-term benthic bloom of cyanobacteria. The macroscopic morphology and color of the domes is characteristic of particular microbialite-building cyanobacterial species. The size of the domes depends on the species, its growth history, and the environment. For example, Phormidium crosbyanum domes characteristically attain 7-20 cm diameter size in French Polynesia (Sprachta et al., 2001) and 4-10 cm diameter in size 
in New Caledonia (Pringault et al., 2005). The microbialite domes are soft to touch and characterized by the accumulation of cyanobacterial sheaths.

The distribution of cyanobacterial trichomes and sheathed filaments in these microbialites have been carefully analyzed by microscopy and their monospecificity has been confirmed by molecular sequencing (Abed et al., 2003a, 2003b). Thus, it was observed that the living trichomes migrate and concentrate along the surface of the structure, leaving behind their sheaths and a network of extracellular polymeric substances (EPS) in the interior. As a result, only the one to three mm thick surface layer is photosynthetically active, as shown by microelectrode measurements (Pringault et al., 2005). In this photosynthetically-active surface layer, carbonate precipitates are rare, limited to scattered encrustations, a few micrometers in size, deposited on cyanobacterial sheaths. In contrast, carbonate precipitates are abundant in the interior of the microbial domes. The inner parts of the microbialite are primarily composed of cyanobacterial sheaths and associated mucilaginous material that towards the interior become gradually decomposed into coalesced and then separated polysaccharide-rich microfibers to form a three-dimensional alveolate organic network.

Heterotrophic bacteria constitute only a minor component of the resident microbiota. They were observed by microscopy but their numbers were low. Oxygen profiles indicated that respiration activities in the interior of the microbialites below the photic zone were extremely low; i.e. the daytime respiration could not compensate for the diffusive delivery of oxygen from the photic zone so that oxygen accumulated to high concentrations (Pringault et al., 2005). In this respect, the Phormidium microbialites are very different from laminated microbial mats growing on the surface of sediments, where cyanobacterial communities are in close contact with very active aerobic and anaerobic bacterial communities.

The carbonate grains in the interior of the microbialite comprise a wide range of shapes and sizes including allochthonous detrital fragments and authigenic precipitates. The bulk of the authigenic calcium carbonate precipitates occurs as 0.1 to $0.2 \mu \mathrm{m}$-sized bodies that are typically closely packed in aggregates and grape-like clusters to form very fine anhedral to subhedral micrite. 
Most of the authigenic calcification in these microbialites is clearly separated in space from the photosynthetically active surface layer, thus not directly coupled to photosynthetic activities of cyanobacteria as has been observed for other systems (Golubic, 1973; Pentecost, 1988; Pentecost \& Bauld, 1988; Spiro \& Pentecost, 1991, Ludwig et al., 2005). Moreover, in the interior of the structures, direct coupling of calcification with other bacterial processes such as ammonification, denitrification, sulfate reduction and anaerobic sulfide oxidation (Buczynski \& Chafetz, 1991; Chafetz \& Buczynski, 1992; Reid et al., 2000; Visscher et al., 2000; Decho, 2000; Decho et al., 2005; Dupraz \& Visscher, 2005; Visscher \& Stolz, 2005) could not be established and appears unlikely in these highly oxidized systems. Instead, the onset and termination of crystal formation appears to be biochemically controlled (Trichet \& Défarge, 1995; Défarge et al., 1996).

Careful extraction and sorting of authigenic micrites from microbialites sampled in Tikehau Atoll, French Polynesia has shown that organic matrices rich in dicarboxilic organic acids (aspartic and glutamic) are tightly associated with the calcium carbonate crystals (Gautret et al., 2004). Peptides with high proportions of dicarboxylic amino acids contain free carboxylic groups that are thought to be involved in the calcification process, since they strongly interact with divalent cations (Gautret \& Trichet, 2005). Other studies have demonstrated that the lithification of modern microbialites results from the interplay between complex processes, both favouring and inhibiting carbonate precipitation. The role of freshly synthesized and intact extracellular polymeric substances (EPS) has been particularly emphasized, since they can sequester $\mathrm{Ca}^{2+}$ and therefore inhibit calcification in the immediate surrounding of photosynthesizing cyanobacterial cells (Arp et al., 1999, 2001; Decho, 2000; Stal, 2000; Pearl et al., 2001; Dupraz \& Visscher, 2005). This capacity may cease following decomposition of the EPS. The connection between calcification and net EPS production in microbial mats has been inferred from a mass balance study (Decho et al., 2005).

The study of organic matrices intimately associated with the minute calcite crystals in the interior of Phormidium spp. microbialites sampled in Tikehau, showed that aminoacids released from degraded EPS were not present in fresh EPS when produced by cyabobacteria. It suggested instead 
that these amino acids potentially derived from different sources.(Gautret et al., 2004). Following alteration processes, EPS degradation products solubilize and diffuse into the pore water of the threedimensional filamentous network, where they mix with allochthonous soluble compounds produced by other organisms living at the sea floor. These compounds may have penetrated from the water column into the microbialite by passive diffusion, or may have arrived agglutinated to sediment particles incorportated in the process of microbialite accretion (Gautret et al., 2004).

The occurrence of similar types of microbialites in two distinct tropical regions, the lagoons of Tikehau atoll (French Polynesia) and of Nouméa (New Caledonia), offers a unique opportunity to trace the impact of environmental conditions on the biochemical composition of organic matrices associated with carbonate precipitates in modern marine microbialites. Among the cyanobacterial species that form the microbialite domes in both areas, our study has been focused on the Phormidium-complex, including P. crosbyanum, P. sp. TK1, and P. hendersonii (Sprachta et al., 2001; Abed et al., 2003a, b). In order to decipher the respective influence of environmental vs. taxonomic factors we have analyzed the amino acid compositions in both habitats, in three structural elements of each of the three species: a) the photosynthetically active surface layer comprising the living cyanobacterial trichomes and freshly synthesized EPS, 2) the three-dimensional alveolate organic network that results from the degradation of cyanobacterial sheaths, and 3) the organic matrices associated with authigenic carbonate precipitates.

\section{ENVIRONMENTAL SETTINGS}

New Caledonia $\left(19-23^{\circ} \mathrm{S}\right.$ and $\left.158-172^{\circ} \mathrm{E}\right)$ is located in the South West Pacific, $1500 \mathrm{~km}$ east of Australia. The climate is mild tropical, with a cool dry season from April to November and a warm rainy season extending from December to March. The temperature of the lagoon surface waters range from 21 to $27^{\circ} \mathrm{C}$ from August to February and are generally similar or very close to that of the open ocean; their salinity does not exhibit significant variations compared to that of the open ocean waters and ranges from 35 to 36 psu. The residence time of the water in the lagoon is estimated to be of 1 to 
2 weeks. The range of the tide is low $(1.8 \mathrm{~m})$. Swells formed by the trade winds come from the East and the Southeast.

The main island covers $19,100 \mathrm{~km} 2$ and hosts the second world's largest reef system after that of the Australian Great Barrier Reef. Fringing reefs are more developed on the eastern coast of the island, whereas, on the western side, barrier reefs enclose two lagoons. The lagoons cover a total area of $24,000 \mathrm{~km} 2$ and are connected to the open ocean by deep passes (50 to $70 \mathrm{~m}$ deep). The Southwestern lagoon (i.e. Nouméa lagoon, see Fig. 1) is funnel shaped and has an average depth of $17 \mathrm{~m}$. It is $100 \mathrm{~km}$ long and runs from the NW to the SE; its width tapers from $40 \mathrm{~km}$ in the SE to about $5 \mathrm{~km}$ in the NW. It contains numerous islets, pinnacles and banks that are fringed by reefs. This lagoon has been impacted from nickel mining, which was practised as open-cast mining from the late 19th century until 1981 (Fernandez et al., 2005). Currently, the lagoon is submitted to increasing anthropogenic impact involving extensive particulate, organic and inorganic supplies that are responsible for increased sedimentation rates and changes in trophic conditions (Bujan et al., 2000).

Tikehau atoll $\left(18^{\circ} \mathrm{S}, 148^{\circ} \mathrm{W}\right)$ is located at the Nortwestern end of the Tuamotu Archipelago (French Polynesia), $300 \mathrm{~km}$ North of Tahiti. The climate is wet tropical, with a warm rainy season from November to the end of April and a cooler dry season from May to October. Monthly average temperatures of the lagoon surface water range from $25^{\circ} \mathrm{C}$ to $32^{\circ} \mathrm{C}$ from August to February and are therefore significantly higher than in the Nouméa lagoon. The water of Tikehau lagoon has a residence time of 25 weeks and a salinity of 35.8 to $36.4 \mathrm{psu}$, which is slightly higher than the surrounding ocean due to evaporation; flushing is therefore much lower than in the Nouméa lagoon. The tidal range is less than $1 \mathrm{~m}$ in Tikehau lagoon and swells formed by the trade winds arrive from the Eastern sector, while larger swells from higher latitudes beat the Southern and Southeastern coast $\mathrm{s}$ of the island.

Tikehau atoll is a typical mid-sized (28 km diameter) and slightly elevated atoll, which is connected to the open ocean by one navigable pass of $300 \mathrm{~m}$ width. The almost circular lagoon with an average depth of $25 \mathrm{~m}$, contains approximately 500 pinnacle reefs ("karenas") and six small 
lagoonal "motu" islets. The soft bottom comprises fine foraminiferal sand grading to white carbonate mud between 20 and 40m; macroalgae (Halimeda and Caulerpa) and sea-grass beds are widespread (Sprachta et al., 2001).

\section{MATERIAL AND METHODS}

\section{Material}

A variety of microbialites, including domes, shapeless gelatinous masses and horizontally spreading mats of various shapes and sizes, occurs in the Nouméa and Tikehau lagoons, especially on the flanks and the slopes of pinnacles and islets and in their vicinity at depth ranging from 0 to $25 \mathrm{~m}$ (Sprachta et al., 2001; Camoin \& Golubic, work in progress). Significant amounts of carbonate precipitates have been observed in domes and gelatinous masses while mats are characterized only by sediment trapping and binding processes.

The present study is focused on the microbialite domes and the gelatinous masses that are produced by virtually monospecific populations of filamentous cyanobacteria belonging to the following species of the genus Phormidium (sensu Gomont, 1892): P. crosbyanum Tilden, $P$. hendersonii Howe, P. laysanense Lemmerman and Phormidium sp. TK1 (Sprachta et al., 2001; Abed et al., 2003a, b). Microbialites were collected in 1998 and 1999 along the flanks and slopes of the pinnacles and "Motu" islets in the Tikehau lagoon where they occur on coral colonies, algal tufts or on the sediment surface between 0 to $25 \mathrm{~m}$ depth (Sprachta et al., 2001). Similar microbialites were sampled in 2001 between 12 and $15 \mathrm{~m}$ depth in the Nouméa lagoon (Fig. 1), except the $P$. crosbyanum microbialite domes from Poé that were collected in a very shallow back-reef setting near Bourail (0.5 to $1 \mathrm{~m}$ depth), about $200 \mathrm{~km}$ north of Nouméa (Table 1).

Two specimens ( $\ll \mathrm{C} »$ in Table 1$)$ collected at Larégnère reef (15 $\mathrm{m}$ depth) have been transferred to an aquarium in Nouméa and maintained for two months in outdoor concrete pools. The concrete pools of $50 \mathrm{~cm}$ depth were filled up to $30-40 \mathrm{~cm}$ water level and continuously flushed with lagoon 
water pumped from the Baie des Citrons (estimated residence time 2 to 5 hours). A black plastic grid was put on top of the pools to reduce the incident light intensity to roughly $20 \%$ of the surface value. Specimens of the coccoid cyanobacterium Entophysalis, and a mat formed by Hydrocoleum sp. were analyzed for comparison with Phormidium domes and gelatinous masses. Microbialite samples were frozen immediately after collection.

\section{Methods}

Systematically we subsampled three structural elements of the domes for hydrolysable amino acid compositions, i.e., i) the photosynthetically active surface layer comprising the living cyanobacterial trichomes and freshly synthesized EPS, ii) the three-dimensional alveolate organic network from the interior, and iii) the organic matrices associated with authigenic carbonate precipitates. Therefore, the relevant pieces of the microbialite were cut out by a scalpel and treated as mentioned below. For the microbialites sampled in Noumea in December 2001, we also analysed photosynthetic pigments for a selection of surface layer subsamples. In addition, one microbialite (i.e. P. crosbyanum collected at Larégnère in June sample 06-01-05, see Table 1) was used for pore water extraction and amino acid analysis of the two molecular weight fractions (MW $<3 \mathrm{kD}$ and $\mathrm{MW}>3 \mathrm{kD}$ ) of dissolved organic matter (DOM). Furthermore, three microbialites collected at different periods of the year 2001, in January (P. crosbyanum, Tabu Reef, sample 01-01-26), in March (P. sp. TK1, M'Bo, sample 03-01-04) and in December (P. crosbyanum, M'Bo, sample 12-01-206) were analyzed for metal concentrations.

The subsamples were lyophilized and dry-weighted, before further treatments. Cyanobacteria and carbonates were gently, mechanically separated and rinsed with MilliQ water. Trapped skeletal fragments were removed through size-decreasing (up to $80 \mu \mathrm{m}$ ) sifts. The finest fraction, so progressively depleted in bioclastic particles, was fractionated for 12 hours by sedimentation in MilliQ water with a few milliliters of sodium hypochlorite both to remove residual filamentous organic matter, and also to avoid further microbial contamination. Fine-grained carbonates occur in two fractions: the first one is deposited at the bottom of the sedimentation column, whereas the other 
one kept suspended in the water column. These two fractions were collected separately and then freeze-dried allowing the recovery of very small grains, a few nanometers in size (Gautret et al., 2004); however, we assume that part of the fine-grained fraction was probably dissolved during the treatment.

\section{Microscopic observations}

Aliquots of fine-grained carbonates were observed under SEM (Philips 505) in order to identify the morphology of carbonate extracts and to control the quality of the extracts regarding the contamination by skeletal grains (refer to SEM pictures in Gautret et al., 2004 for the comparison between grain morphologies before and after extraction).

Other samples were sprayed on glass slides previously covered of araldite. After polymerization and room-temperature drying, the preparations were polished. Staining techniques have been used to study in situ distribution of organic substances in carbonate particles extracted from microbialites. Acridine Orange (Sigma-Aldrich prod. A6014; 0.2\% aqueous solution) was first applied for 3 minutes in order to visualize the acidic mucopolysaccharids. Fluorescence of acridine orange-stained surfaces were observed under ultraviolet light using a Zeiss Standard microscope equipped with Neofluar objectives, a Zeiss mercury lamp, excitation filters at $365 \mathrm{~nm}$ (UV excitation) and $435 \mathrm{~nm}$ (blue excitation) and a transmission cutt-off filter $(400 \mathrm{~nm})$. The preparations were next stained with Aniline Blue. Proofs were prepared by fine-sectioning wet pieces just before freeze-drying of entire microbialites. They were mounted on glass-slides and examined under the light microscope.

\section{Biochemistry}

Carbonate samples were decalcified in acetic acid (12hrs, $\mathrm{pH} 4$ automatically controlled by a titrimeter) and centrifuged to separate insoluble organic matrices (IOM). The supernatant, which contains the soluble organic matrices (SOM) was filtered and separated from Ca-salt by desalting gel- 
filtration chromatography with a Sephadex G25 column or with a Fast-Desalting (Pharmacia) column, with a UV $(280 \mathrm{~nm})$ detection. The purification of soluble matrices was completed by ultra filtration (MilliQ water; in Filtron Novacel 10 ml, cut-off 3KD). Desalting of very small samples (5 to $15 \mathrm{mg}$ ) was performed directly by ultrafiltration using centrifugal concentrators for biomolecular separations (Pall Filtron, Microsep 3K for $3.5 \mathrm{ml}$ or less, or Nanosep $3 \mathrm{~K}$ for $50-500 \mu \mathrm{l}$ ). Purified organic matrices were then lyophilized.

Ultrafiltration in centrifugal concentrators was also used for separation of two size fractions in dissolved organic matter (DOM) of pore water.

Decalcified pieces of the bulk organic matter of the photosynthetically active surface and of the alveolate organic network of the interior, organic matrices extracted from carbonates, as well as DOM were all subjected to $6 \mathrm{~N} \mathrm{HCl}$ hydrolysis $\left(24 \mathrm{hrs}, 110^{\circ} \mathrm{C}\right.$ in free-air sealed tube), vacuum drying (speed/vac) and derivatization with phenyl-isothiocyanate (PITC). The composition of the hydrolysable amino acids was determined by HPLC-reversed phase chromatography using Hypersil ODS $5 \mu \mathrm{m}, 250$ x $4.6 \mathrm{~mm}$ column, acetonitrile gradient, and $254 \mathrm{~nm}-\mathrm{UV}$ detection. Relative concentration in residue $\%$ and absolute weights were determined with respect to a standard (Beckman amino acid kit). Pyrolysed glass vials were used for the biochemical analyzes.

Pigments were separated by reverse-phase HPLC using Thermo-Finnigan equipment (ThermoFinnigan, France) on a Lichosphere RP8 $(5 \mu \mathrm{m}, 25 \mathrm{~cm}, 4 \mathrm{~mm}$ i.d) column (Cluzeau, Saint-Foy, France) following the method of Barlow et al. (1997), using a binary gradient from A (70\% methanol/ 30\% $1 \mathrm{M}$ aqueous ammonium acetate buffer, $\mathrm{pH}=7.2$ ) to $\mathrm{B}$ (methanol). The methanol extracts were diluted with aqueous ammonium acetate (final content 30\%) four minutes prior to injection by a Thermo-Finnigan (TSP AS3000) sample preparation and automatic injector. A Thermo-Finnigan UV6000 diode-array spectrophotometer was programmed to obtain the on-line absorption spectra from 320 to $800 \mathrm{~nm}$. Pigments were identified by comparing their retention time and absorption spectra with those of authentic standards (International Agency for 14C Determination) and quantified using the areas and response factors at $440 \mathrm{~nm}$. 


\section{Metal analysis}

Homogenized samples of microbialites were analyzed after acidic dissolution, by inductively coupled plasma atomic emission spectrometry (ICP-AES) using a Jobin-Yvon ULTIMA spectrometer for the determination of metals concentrations. Blank tests were performed as well as the analyses of a certified standard (estuarine sediment, LGC 6137) for the comparison of the data obtained.

\section{Statistical treatments}

KyPlot 2 beta 15 software was used to plot bivariate correlations and frequency histograms and to perform multivariate principal component analysis (PCA), a multivariate technique for reducing matrices of data to their lowest dimensionality by the use of orthogonal factor space. Multiple correlated variables are summarized in one single factor (principal component). Basically extraction of principal components amounts to a variance maximizing rotation of the original variable space. Because first principal component is defined to represent most of the total variability, and each other consecutive factor to maximize the variability that is not captured by the preceding one, consecutive factors are independent of each other. Factor loadings reflect correlations between two factors (i.e., "new" variables); their plot shows each variable as a point. Factor scores allow one to estimate the actual values of individual cases (analyzed samples) for the considered principal components.

\section{RESULTS}

\section{Pigments}

Table 2 gives the contents of lipophilic pigments extracted from the photosynthetically active surface layer of the microbialites sampled in December 2001 in the Nouméa lagoon. All samples contain chlorophyll a, zeaxanthin and $\beta$-carotene that all characterize cyanobacteria. The cyanobacterial 
carotenoid myxoxanthophyll was only observed in Phormidium crosbyanum and P. laysanense, but not in P. hendersonii and Phormidium TK1. The highest and lowest values of chlorophyll a have been observed for $P$. crosbyanum sampled at $12 \mathrm{~m}$ depth and $1 \mathrm{~m}$ depth, respectively. In a recent study (Pringault et al., 2005) pigment content and photosynthetic parameters were studied for different microbialites built by P. crosbyanum and Phormidium TK1. The latter is a typical low-light adapted species that occurs in the lagoon between 13 and $20 \mathrm{~m}$ depth, which lacks myxoxanthophyll involved in the protection against photon damage at high light. In contrast, $P$. crosbyanum has been observed in depths between 0 and $18 \mathrm{~m}$ depth (although rarely below $13 \mathrm{~m}$ ). This species adapts its photosynthetic machinery and pigment contents to the prevailing light conditions, so that its chlorophyll content increases with depth.

The sampled domes with $P$. crosbyanum, and Phormidium TK1 also contain fucoxanthin, a carotenoid that is characteristic of diatoms. This has been confirmed by microscopic observations of benthic pennate diatoms on the surface of the domes. Diatoms were numerous in the samples collected from January to June 2001, but rather low in samples collected in December of that year.

\section{Hydrolysable amino acid compositions of the photosynthetically active surface layer and of the interior three-dimensional alveolate organic network}

Fig. 2 compares the weight proportion of proteins in the bulk organic matter of the photosynthetically active surface layer and the interior alveolate network of microbialites built by the different Phormidium species sampled in New Caledonia. P. laysanense yields the highest protein content. $P$. crosbyanum samples display intermediate values, while $P$. hendersonii samples are characterized by the lowest contents. In all cases, the protein content of the organic matter (OM) was the highest at the surface of the microbialite dome and lower in the interior. In most cases, an average loss of about 50 $\%$ of the protein content (range 20 to $70 \%$ ) characterizes the transition from the photosynthetically active surface layer towards the internal parts of the microbialites. The photosynthetically active surface layer comprises the living filaments, i.e. cyanobacterial cellular trichomes with sheaths, while 
the alveolate interior is mainly composed of empty cyanobacterial sheaths that undergo progressive degradation. As the microbialite grows and increases in diameter, the living trichomes move phototactically to the surface layer, leaving only their sheaths behind. The difference in protein content between the surface and the interior reflects, therefore, mainly the contribution of living cyanobacterial trichomes in the surface layer. A minor part of this difference could be attributed to selective degradation processes, with proteins representing a more labile fraction than average OM.

The hydrolysable amino acids of the bulk organic matter samples (comprising both the photosynthetically active surface layer and the interior of the dome) of the microbialites collected in the Nouméa lagoon were compared by a Principal Component Analysis (Fig. 3). The projection of the 35 analyzed samples on components 1 and 2 of the PCA-score plot displays a continuous sorting of fields defined by the various Phormidium species (Fig. 3). This continuum is characterized by two end members, i.e. $P$. laysanense and $P$. sp. TK1 which are characterized by higher concentrations in aspartic and glutamic acids, serine, histidine, lysine and tyrosine (Asp, Glu, Ser, His, Lys, Tyr), and by higher concentrations in leucine, isoleucine, valine, phenylalanine, glycine, hydroxyproline and proline (Leu, Ile, Val, Phe, Gly, Hypro, Pro), respectively. Between these two end members, the different successive fields observed correspond to those of $P$. crosbyanum, and $P$. hendersonii, respectively. Nevertheless, this plot shows a lot of overlap between species, thus indicating that interspecies variability was low compared with intraspecies variability. Therefore, the amino acid composition does not allow an unambiguous identification of the taxonomic origin of the organic networks.

In addition to the signatures of the nature of the material analyzed and of the taxonomic origin of cyanobacterial communities, the overall amino acid composition is related to the sampling site, suggesting therefore that this signature is also influenced by environmental parameters. The sampling sites in the lagoon are reported on the graph of sample projection (Fig. 3, lower panel). The fields including samples collected at Poé, M’Bo, Amédée, Snark and Larégnère surround the field 
containing samples collected in Sainte Marie area that corresponds to a large and quiet bay. Samples that were collected at Larégnère and then maintained for one month in an aquarium in Nouméa, occupy an outlier position in the field formed by the Larégnère samples.

Principal component analysis of hydrolysable amino acids in the photosynthetically active surface layers of microbialite samples from New Caledonia and Tikehau is illustrated in Fig. 4. Samples of these two regions display a distinctive amino acid composition and most of New Caledonian samples are sorted out the "Tikehau-field". The microbialites sampled during the January-June 2001 period cluster together and are separated along axis 1 of the PCA from the microbialites sampled later (December) and from all the Tikehau microbialites (Fig. 4). The microbialites sampled between January and June 2001 are characterized by high leucine and isoleucine contents and coeval relatively high amounts of Phe, Tyr and Lys, and lower concentrations of Pro, Hypro, His, Asp and Glu compared to the others. However, variability in time is shown by the distribution pattern of samples collected in New Caledonia at the end of year 2001 (December 2001) that overlaps that of the Tikehau microbialites suggesting that the bulk composition of surface layers in the January-June time window has been influenced by an environmental event.

\section{Hydrolysable amino acid compositions of organic matrices associated with calcium carbonate precipitates}

There are two types of fine-grained carbonates extracted from microbialites. Each is characterized by distinctive morphologies and textures.

The first type of carbonate grains (Fig. 5) consists of carbonate tubes, up to $10 \mu \mathrm{m}$ thick, that were fragmented during the preparation. Such carbonate tubes completely surround degraded cyanobacterial sheaths in the interior of microbialite domes (see Sprachta et al., 2001 for the Tikehau counterparts), whereas they are more scattered and thinner in superficial layers. Similar encrustations have been described in microbial fabrics from various environments, including tufa formed in 
freshwater streams (Merz-Preiss \& Riding, 1999), or in "kopara" deposits (Défarge et al., 1994, 1996). The broken pieces of these tubes display a 2-3 $\mu \mathrm{m}$ hole in their center which often still contains a piece of the cyanobacterial sheath which has been kept pinched and trapped (Fig. 5A); their structure is typically composed of anhedral crystals. The organic compounds associated with this type of carbonate encrustation are faintly stained with the non-fluorescent aniline blue (Fig. 5B), whereas the fluorescent dye Acridine Orange bound onto the overall section of such particles exhibits a very bright yellow-orange fluorescence under the blue light-excitation (Fig. 5C). However, the pieces of cyanobacterial sheaths are identified under the selective UV light-excitation, as a red fluorescent area restricted to the center of the particles (Fig. 5D).

The second type of carbonate grains (Fig. 6) corresponds to the "micropeloids" described in Tikehau microbialites (Sprachta et al., 2001) that occur in the alveolar organic network where they are associated with the decayed cyanobacterial fabric. They form cauliflower-like carbonate elements exhibiting a spheroid to more or less elongated, sometimes very irregular, shape, and a typical mamillated surface (Fig. 6A). They are composed of closely packed very fine micritic grains secondarily overgrown by euhedral calcite crystals (“ageing processes”, Sprachta et al., 2001). Aniline blue staining reveals a dense mucilaginous template beneath the clustered arrangement of the grains (Fig. 6B, 6E). Like for the sheaths, the filamentous, cyanobacterially-derived organic matter agglutinated with carbonate grains exhibits a bright yellow-orange under blue light excitation, and orange-red fluorescence under UV excitation (Fig. 6C, 6D).

Figures 7 and 8 illustrate the frequency distributions of the concentration of selected hydrolysable amino acids in the soluble and insoluble organic matrices (SOM and IOM, respectively) associated with the in-situ precipitated carbonates for the two sets of samples. The SOM and IOM extracted from New Caledonian samples are characterized by very high levels of cysteine, a sulphurcontaining amino acid, while this amino acid was only occasionally detected in the SOM and IOM from Tikehau samples. We assume that when present at high concentrations, most of the cysteine 
would survive the $6 \mathrm{~N} \mathrm{HCl}$ acidic treatment and we therefore expect that the reported proportions of cysteine are slightly underestimated in the SOM and IOM of New Caledonian samples. The cysteine contents of the different SOM and IOM samples are reported in Table 3, which for comparison also includes the values for the dissolved organic matter in the analyzed pore water sample. The lowest cysteine proportions (12 to 18\%) are recorded in SOM associated with carbonates that precipitated in P. crosbyanum and $P$. sp. TK1 microbialites collected in the Larégnère area. The high molecular weight fraction $(\mathrm{MW}>3 \mathrm{kD})$ of dissolved organic matter in interstitial waters from another $P$. crosbyanum microbialite dome collected in the Larégnère area, exhibits a similar cysteine content (17.3\%). The cysteine proportion in SOM extracted from other microbialites is significantly higher. The $P$. crosbyanum microbialite collected in Poé back-reef setting is characterized by an intramineral SOM containing $25 \%$ of cysteine, whereas the cysteine content ranges from $27.5 \%$ to $28 \%$ in $P$. hendersonii and P. sp. TK1 microbialites collected at Amédée. The highest content in cysteine $(34.4 \%)$ has been reported in the low molecular weight fraction $(\mathrm{MW}<3 \mathrm{kD})$ of the pore water sample (P. crosbyanum microbialite, from the Larégnère area).

The range of cysteine contents is broader in IOM extracted from the carbonate precipitates (Table 3; Fig. 8). The two samples that are characterized by contents lower than $10 \%$ belong to microbialites produced by Phormidium sp.TK1 that were collected in Larégnère and Amédée areas respectively. The intramineral concentrations measured in $P$. crosbyanum domes are significantly higher and range from $14.5 \%$ in Larégnère and Poé samples to $23.8 \%$ and up to $32.8 \%$ in Larégnère samples. The highest concentrations were found in the intramineral IOM from the $P$. hendersonii microbialites that contains up to $40.5 \%$ in cysteine, even more than the content measured in low molecular weight organic matter dissolved in interstitial pore waters. It is noteworthy that this microbialite dome was collected in the same site as the Phormidium sp. TK1 in which the intramineral IOM contains only $9.8 \%$ of cysteine, thus suggesting a strong taxonomic control on the cysteine concentrations in intramineral IOM.

Correlations between the concentrations in cysteine and other amino acids measured in 
intramineral matrices were tested. The highest coefficient is found with the total quantity of matrix, then with concentrations of leucine and isoleucine, as positive correlations. Reverse correlations are found with histidine and aspartic acid.

In order to look for additional differences between the hydrolysable amino acids of the SOM and IOM matrices associated with the in situ-carbonate precipitates, we compared the samples by a PCA after excluding the contribution of cysteine (Fig. 9). This analysis clearly illustrates the compositional difference of organic matrices in the two areas. The two IOM clusters, although adjacent, are separated according to their geographical origin, while SOM clusters are distributed within two distinctive areas, according to their geographical origin. The amino acids that contribute in sorting samples along component 1 are dicarboxylic amino acids (Asp and Glu), opposite to hydrophobic amino acids (Leu, Ile, Val, Phe). The depletion in histidine (His) in SOM and IOM associated with carbonates in New Caledonia also participates (component 2) in the distinction between Polynesian and New Caledonian microbialites.

To summarize, if we exclude the cysteine contribution, the New Caledonian microbialites are characterized by an amino acid composition of SOM, that is dominated by glycine (21\%), alanine (17.3\%) and valine (8\%). Glutamic acid (7.8\%) and aspartic acid (6.7\%) are well represented but unlike soluble matrices extracted from the Tikehau microbialites (see Gautret et al., 2004), they do not correspond to the dominant amino acids. Amino acid composition of IOM is dominated by proline $(15.2 \%)$, glycine $(14 \%)$ alanine $(13.2 \%)$ and valine $(12.1 \%)$. Concentrations in leucine and isoleucine are respectively of $9.2 \%$ and $8.1 \%$. Dicarboxylic amino acids, Asp and Glu, are poorly represented with concentrations of $3.75 \%$ and $4.9 \%$ respectively.

\section{Metal concentrations}

Table 4 summarizes the concentrations obtained in 2 analyses of each microbialite sample and 2 analyses of the certified sample (CRM, LGC 6137). Taking in account our overestimation of $\mathrm{Cr}$ 
concentrations (cf. certified sample), we can consider that the Phormidium microbialite collected in January did not contain significant heavy metal concentrations. In contrast, $\mathrm{Cr}$ and $\mathrm{Ni}$ have been detected in the sample collected in March, whereas $\mathrm{Cr}$, Ni and $\mathrm{Zn}$ occur in the microbialite collected in December. The presence of these metals in microbialite fabrics may reflect the incorporation of terrigenous particles, which are rich in $\mathrm{Ni}, \mathrm{Cr}$ and $\mathrm{Zn}$ (Fernandez et al., 2005).

\section{DISCUSSION}

The study of lagoonal microbialite domes in the lagoon of Tikehau has shown that the intramineral organic matrices are selectively derived from the bulk organic matter, leaving a clear albeit degradationally modified signature of the taxonomic identity of the particular microbialite building cyanobacterium that persisted in the IOM and SOM associated with the calcite crystals (Gautret et al., 2004). The predominance of the dicarboxylic acids in the intramineral matrices of the Phormidium microbialites sampled in Tikehau was in good agreement with the idea that peptides with free carboxylic groups are mechanistically implied in the onset and biochemical control of the formation of the micropeloid calcium carbonate precipitates (Gautret et al. 2004, Gautret \& Trichet, 2005). A different amino acid composition, however, was found in organic matrices incorporated in carbonate precipitates in the lagoon of New Caledonia (Fig. 10). Here the very high cysteine content of the intramineral matrices suggests that intramineral peptides are derived from cysteine-rich proteins and peptides of unknown origin. Occasional sampling of pore water in a $P$. crosbyanum microbialite, for example, shows that the different molecular weight fractions of dissolved organic matter are also very rich in cysteine. However, the bulk organic matter of these microbialites is not particularly rich in cysteine, which strongly suggests that soluble peptides initially not associated with the carbonate grains that occur in the pore water of the microbialite, may become an important source for the SOM and IOM associated with the carbonate grains.

The presence of such unusual compounds in microbialites of New Caledonia leads to invoke 
the presence of metallothioneins which are specific peptides often containing above $30 \%$ of cysteine (Grill et al., 1985; Rauser, 1995; Cobbett, 2000) and disulfide crosslinking of two cyteine residues which is common in trans-membrane and extracellular proteins (Calissano et al., 1976; Cho et al., 2000). Cysteine-rich metallothioneins are not widely distributed among bacterial species, but their occurrence has been described in various cyanobacterial species such as Synechococcus and Anacystis (Gupta et al., 1992, 1993; Turner \& Robinson, 1995; Robinson et al., 2000; Busenlehner et al., 2003), where they are synthesized in response to stress related to inputs of heavy metals (e.g. zinc and copper). Metallothioneins that bind the bivalent metals to cysteine to form metal-thiolate clusters are generally intracellular and have been involved in the control of intracellular concentrations of essential metal ions as well as in the protection against toxic levels of these metals in the environment. It has also been observed recently that extracellular slime in the cyanobacterium Synechocystis aquatilis is able to sequester zinc ions, but the nature of this extracellular matrix has not been studied (Magalhães et al., 2004). Phytochelatin, which is a small-sized class III metallothionein, has been identified in different classes of microalgae (e.g. Gekeler et al., 1988; Ahner et al., 1995; Morelli \& Scarano, 2001). Ahner \& Morel (1995) quantified phytochelatin in the marine diatom Thalassosira weissflogii, after exposure to a series a trace metals. $\mathrm{Cd}$, followed by $\mathrm{Cu}$ and $\mathrm{Zn}$ were found to be the most effective inducers of phytochelatin, the rapid formation and elimination of which being regulated by the cell as a consequence of $\mathrm{Cd}$ exposure and alleviation. At high $\mathrm{Cd}$ concentrations, $T$. weissflogii exports the cadmium-phytochelatin complex as a detoxification mechanism to seawater where it does not appear to be stable as soon as it is released by the cell (Lee et al., 1996). Assuming that the cysteine in IOM and SOM matrices associated with carbonate crystals and in the pore water peptides was derived from metallothionins, it remains an open question whether these were produced by Phormidium or by diatoms. In this respect, it is noteworthy that frustules of pennate diatoms have been observed in New Caledonian microbialites and that fucoxanthin, the carotenoid pigment that typifies diatoms, has been detected in the photosynthetically active top layer, thus demonstrating that pennate epiphytic diatoms lived on the cyanobacterial structure. 
Metallothionein synthesis is stimulated by the occurrence of heavy metal, accordingly pointing to a significant difference between lagoonal environments of the two studied sites. The mainland of New Caledonia is composed of tropical laterites rich in metals; the nickeleforous peridotites are especially rich in $\mathrm{Ni}, \mathrm{Cr}$ and $\mathrm{Zn}$ in decreasing order. Deforestation and significant open-cast mining activities have been prevalent throughout the history of New Caledonia, especially during the past century. Although $\mathrm{Ni}$ and $\mathrm{Zn}$ concentrations in the water column are generally low, the heavy-metal concentrations reported in Phormidium microbialites confirm that the benthic compartment has been enriched in these metals, as a consequence of inputs of dust and sediments in the lagoon in early 2001. A recent study has shown that terrigenous particles rich in $\mathrm{Ni}, \mathrm{Cr}$ and $\mathrm{Zn}$ transported to the lagoon by the Coulée river tributary are then dispersed by currents to distal zones along the coastline (Fernandez et al., 2005). The transportation patterns and the incorporation of these particles to the open lagoon sediments would deserve further studies.

An alternative explanation may be that the cysteine-rich proteins were derived from allochthonous sources. The microbialites are known to agglutinate skeletal materials and organic detritus from both bottom-dwelling fauna and benthic (algae, phanerogams) and planktonic (phytoplankton) autotrophs. Glycine, proline and hydroxyproline are abundant in muci and degradational products of metazoans, such as those released by sponges, scleractinian corals, and hydrozoans, among others. These compounds have been commonly observed in organic matrices associated with carbonate precipitates in various microbialites, suggesting that they can be interpreted as useful "biomarkers" of the biota that lives in these environments (Reitner et al., 1995; Camoin et al., 1999). The insoluble organic matrix (IOM) associated with carbonates in New Caledonian microbialites is enriched in proline and hydroxyproline, suggesting that inputs from bottom-dwelling organisms contributed to the amino acid compositions and may have therefore influenced the organomineralization processes. 
It is conceivable that soluble peptides rich in cyteine are conserved in the intramineral matrices, since the electronegative charge of the S-atom in the sulfhydryl group has some affinity to the bivalent calcium ions. Such a mechanism may explain why the intramineral matrix becomes progressively enriched in cysteine compared to the bulk organic matter derived from the cyanobacterial trichomes, sheaths and other EPS together with additional inputs from epiphytic diatoms. Aspartic and glutamic acids are present in significant amounts in intramineral matrices, but are clearly subordinate to Cys, Leu, Ala, Arg and Pro. The involvement of cysteine in calcification processes is still an open question.

During the first half of year 2001, amino acid compositions of the bulk organic matter both in the photosynthetically active surface layers and in the interior of the New Caledonian microbialites are strongly deviated from those observed in the Tikehau microbialites, while they are similar to the latter in the second part of the year (Fig. 10). It seems therefore unlikely to attribute this difference entirely to phenotypical variation of Phormidium trichome and sheath material, but rather to an external factor. The occurrence of pennate diatoms in the top layer can explain most of this variability. Diatoms are particularly abundant in the samples collected during the January to June 2001 period, while they are significantly scarcer in the microbialites collected in December 2001. It is noteworthy that amino acid compositions of the bulk organic matter in the photosynthetically active top layer of New Caledonian samples collected in December are similar to those analyzed in Tikehau microbialites. This suggests i) that the most labile proteinaceous fraction issued from diatom infestation was completely degraded, when high values of fucoxanthin have been reported in those samples, demonstrating the importance of including photosynthetic pigment analyses in biomarker studies regarding cyanobacterial microbialites, ii) that the end of year 2001 reflects normal conditions of the lagoonal environment where the fundamental functioning of dome-shaped microbialites built by cyanobacteria should be similar in both French Polynesia and New Caledonia, including biochemistry of the different compartments of organic matter. 
The variability in amino acid composition throughout the year 2001 in New Caledonia may potentially reflect either the impact of exceptional climatic events or a much stronger seasonality climate than in French Polynesia. The cyclone Paula hit New Caledonia by the end of February and beginning of March 2001. Such a cyclone is expected to have had a very strong impact on the lateral transport in the lagoon and on the survival and the growth mode of benthic cyanobacteria and diatoms, i.e. the production of Cys-rich peptides as a reaction to the time-limited metal exposure following the sudden input of toxic loads of metals in the lagoon.

\section{ACKNOWLEDGMENTS}

This work was by a grant of the Programme National Environnement Côtier (PNEC) and was carried out during a two-year research period (G.C.) at the IRD Center in Nouméa (UR055 "Paléotropique"). The authors wish to thank Patrick Baillif (ISTO, Orléans) for metal analyses, Jean Louis Menou and Christophe Peignon, IRD Center, Noumea for assistance in sampling. International collaboration was supported by Hanse Institute for Advanced Studies, Delmenhorst, and Alexander-von-Humboldt Foundation, Bad Godesberg, Germany (S.G.). We are indebeted to three anonymous reviewers and to Kurt Konhauser for their valuable comments, which certainly improved the manuscript.

\section{REFERENCES}

Abed R, Golubic S, Garcia-Pichel F, Camoin G, Seong-Joo L (2003a) Identity and speciation in marine benthic cyanobacteria: The Phormidium-complex. Algological Studies, 109, 35-56.

Abed R, Golubic S, Garcia-Pichel F, Camoin G, Sprachta S (2003b) Characterization of microbialiteforming cyanobacteria in a tropical lagoon: Tikehau atoll, Tuamotu, French Polynesia. Journal of Phycology, 39, 862-873 
Ahner BA, Kong S, Morel FMM (1995) Phytochelatin production in marine algae. 1. An interspecis comparison. Limnology and Oceanography, 40, 649-657.

Ahner BA, Morel FMM (1995) Phytochelatin production in marine algae. 2. Induction by various metals. Limnology and Oceanography, 40, 658-665.

Arp G, Reimer A, Reitner J (2001) Photosynthesis-induced biofilm calcification and calcium concentrations in Phanerozoic oceans. Science, 192, 1701-1704.

Arp G, Thiel V, Reimer A, Michaelis W, Reitner J (1999) Biofilm exopolymers control microbialite formation at thermal springs discharging into the alkaline Pyramid Lake, Nevada, USA. Sedimentary Geology, 126, 159-176.

Barlow RG, Cummings DG, Gibb SW (1997) Improved resolution of mono- and divinyl chlorophylls $\mathrm{a}$ and $\mathrm{b}$ and zeaxanthin and lutein in phytoplankton extracts using reverse phase C-8 HPLC. Marine Ecology Progress Series, 161, 304-307.

Buczynski C, Chafetz HS (1991) Habit of bacterially induced precipitates of calcium carbonate and the influence of medium viscosity on mineralogy. Journal of Sedimentary Petrology, 61, 226-233.

Bujan S, Grenz C, Fichez R, Douillet P (2000) Evolution saisonnière du cycle biogéochimique dans le lagon sud-ouest de Nouvelle-Caledonie. Application d'un modèle compartimental. Comptes Rendus de l'Académie des Sciences, Paris, 323, 225-233. 
Busenlehner LS, Pennella MA, Giedroc DP (2003) The Smt/ArsR family of metalloregulatory transcriptional repressors: structural insights into prokaryotic metal resistance. FEMS Microbiology Reviews, 27, 131-143.

Calissano P, Mercanti D, Levi A (1976) $\mathrm{Ca}^{2+}, \mathrm{K}^{+}$-regulated intramolecular crosslinking of S-100 protein via disulfide bond formation. European Journal of Biochemistry, 71, 45-52.

Camoin G, Gautret P, Montaggioni L, Cabioch G (1999) Nature and environmental significance of microbialites in Quaternary reefs: the Tahiti paradox. Sedimentary Geology, 126, 271-304.

Chafetz HS, Buczynski C (1992) Bacterial induced lithification of microbial mats. Palaios, 7, 273293.

Cho HC, Tsushima RG, Nguyen TT, Guy HR, Backx PH (2000) Two critical cysteine residues implicated in disulfide bond formation and proper folding of Kir2.1. Biochemistry, 39, 4649-4657.

Cobbett C.S (2000) Phytochelatins and their roles in heavy metal detoxification. Plant Physiology, 123, 825-832.

Decho A (2000) Microbial biofilms in intertidal systems: an overview. Continental Shelf Research, 20, 1257-1273. 
Decho A, Visscher PT, Reid P (2005) Production and cycling of natural microbial exopolymers (EPS) within a marine stromatolite. Palaeogeography, Palaeoclimatology, Palaeoecology, 219, 7186.

Défarge C, Trichet J, Jaunet AM, Robert M, Tribble J, Sansone F (1996) Texture of microbial sediments revealed by cryo-scanning electron microscopy. Journal of Sedimentary Research, 66, 935947.

Défarge C, Trichet J, Maurin A, Hucher M (1994) Kopara in Polynesian atolls; early stages of formation of calcareous stromatolites. Sedimentary Geology, 89, 9-23.

Dupraz C, Visscher P (2005) Microbial lithification in marine stromatolites and hypersaline mats. Trends in Microbiology, 13, 429-438.

Fernandez JM, Ouillon S, Chevillon Ch, Douillet P, Fichez R, Le Gendre R (2005) A combined modelling and geochemical study of the fate of terrigenous inputs from mixed natural and mining sources in a corral reef lagoon (New Caledonia). Marine Pollution Bulletin, in press

Gautret P, Camoin G, Golubic S, Sprachta S (2004) Biochemical control of calcium carbonate precipitation in modern lagoonal microbialites, Tikehau Atoll, French Polynesia. Journal of Sedimentary Research, 74, 462-478.

Gautret P, Trichet J (2005) Automicrites in modern cyanobacterial stromatolitic deposits of Rangiroa, Tuamotu Archipelago, French Polynesia: biochemical parameters underlaying their formation. 
Sedimentary Geology, 178, 55-73.

Gekeler W, Grill E, Winnacker E, Zenk MH (1988) Algae sequester heavy metals via synthesis of phytochelatin complexes. Archives of Microbiology, 150, 197-202.

Golubic S (1973) The relationship between blue-green algae and carbonate deposits. In: The Biology of Blue-Green Algae (eds. Carr NB, Whitton BA), Blackwell Scientific Publications, Oxford, U.K., pp. 434-472.

Gomont M (1892) Monographie des Oscillariees. Ann. Sci. Nat., Bot., Ser. 7, 15, 263-368; 16, 91264.

Grill E, Winnacker EL, Zenk MH (1985) Phytochelatins: The principal heavy-metal complexing peptides of higher plants. Science 230, Issue 4726, 674-676.

Gupta A, Whitton BA, Morby AP, Huckle JW, Robinson NJ (1992) Amplification and rearrangement of a prokaryotic metallothionein locus smt in Synechococcus PCC6301 selected for tolerance to cadmium. Proceedings of the Royal Society London B, 248, 273-281.

Gupta A, Morby AP, Turner JS, Whitton BA, Robinson NJ (1993) Deletion within the metallothionein locus of cadmium tolerant Synechococcus PCC6301 involving a highly iterated palindrome (HIP1). Molecular Microbiology, 7, 189-195.

Lee JG, Ahner BA, Morel FMM (1996). Export of cadmium and phytochelatin by the marine diatom 
Thalassiosira weissflogii. Environmental Science and Technology, 30, 1814-1821.

Ludwig R, Al-Horani, FA, De Beer D, Jonkers HM (2005) Photosynthesis controlled calcification in a hypersaline microbial mat. Limnology and Oceanography, 50, 1836-1843

Magalhães CCP, Cardoso D, Dos Santos CP, Chaloub RM (2004) Physiological responses of Synechocystis aquatilis f aquatilis (Cyanophyceae) to elevated levels of zinc. Journal of Phycology, 40, 496-504.

Merz-Preiss M, Riding R (1999) Cyanobacterial tufa calcification in two freshwater streams: ambient environment, chemical thresholds and biological processes. Sedimentary Geology,126, 103-124.

Morelli E, Scarano G (2001). Synthesis and stability of phytochelatins induced by cadmium and lead in the marine diatom Phaeodactylum tricornutum. Marine Environmental Research, 52, 383-395.

Pearl HW, Steppe TF, Reid RP (2001) Bacterially mediated precipation in marine stromatolites. Environmental Microbiolology, 3, 123-130.

Pentecost A (1988) Growth and calcification of the cyanobacterium Homoetothrix crustaceae. Journal of General Microbiology, 134, 2665-2671.

Pentecost A, Bauld J (1988) Nucleation of calcite on the sheaths of cyanobacteria using a simple diffusion cell. Geomicrobiology Journal, 6, 129-135 
Pringault O, De Wit R, Camoin G (2005). Irradiance regulation of photosynthesis and respiration in modern marine microbialites built by benthic cyanobacteria in a tropical lagoon (New Caledonia). Microbial Ecology, 49, $604-616$.

Rauser W (1995) Phytochelatins and related peptides. Plant Physiology, 109, 1141-1149.

Reid RP, Visscher P, Decho A, Stolz J, Bebout BM, Macintyre I (2000) Microbial lithification in modern stromatolites. Nature, 406, 989-992.

Reitner J, Gautret P, Marin F, Neuweiler F (1995) Automicrites in a modern marine microbialite. Formation model via organic matrices (Lizard Island, Great Barrier Reef, Australia). Bulletin de l'Institut Océanographique de Monaco, 14( 2), 237-263.

Robinson NJ, Rutherford JC, Pocock MR, Cavet SJ (2000) Metal metabolism and toxicity: repetitive DNA. In: The ecology of cyanobacteria (eds. Whitton BA, Potts M). Kluwer Academic Publisher, Dordrecht, pp. 443-446

Spiro B, Pentecost A (1991) One day in the life of a stream - a diurnal inorganic carbon mass balance for a travertine-depositing stream (Waterfall Beck, Yorkshire). Geomicrobiology Journal, 9, 1-11.

Sprachta S, Camoin G, Golubic S and Le Campion T (2001) Microbialites in a modern lagoonal environment: nature and distribution (Tikehau atoll, French Polynesia): Palaeogeography, Palaeoclimatology, Palaeoecology, 175, 103-124. 
Stal. LJ (2000) Cyanobacterial mats and stromatolites. In: The ecology of cyanobacteria (eds. Whitton BA, Potts M). Kluwer Academic Publisher, Dordrecht, pp. 61-120.

Trichet J, Défarge C (1995) Non-biologically supported organomineralization. Bulletin de l'Institut Océanographique de Monaco, 19, 203-208.

Turner JS, Robinson NJ (1995) Cyanobacterial metallothioneins: biochemistry and molecular genetics. Journal of Industrial Microbiology, 14, 119-125.

Visscher PT, Reid RP, Bebout BM (2000) Microscale observations of sulfate reduction: correlation of microbial activity with lithified micritic laminae in modern marine stromatolites. Geology, 28, 919-922.

Visscher PT, Stolz JF (2005) Microbial mats as bioreactors: populations, processes, and products. Palaeogeography, Palaeoclimatology, Palaeoecology, 219, 87-100. 


\section{Tables}

Tabl. 1. List of samples analyzed for amino acid compositions

OM, organic matter comprising 2 separate analyses, i.e. the photosynthetically active surface layer and the interior of microbialites; SOM, soluble organic matrix associated with carbonates; IOM, insoluble organic matrix associated with carbonates; DOM, dissolved organic matter in pore water associated with microbialites.

Tabl. 2. Lipophilic pigment contents in the photosynthetically active surface layer of microbialites sampled in New Caledonia in December 2001.

Tabl. 3. Apparent cysteine contents in organic matrices (SOM and IOM) associated with carbonates and in pore water (low- and high molecular weight fractions of DOM). 
Figure captions

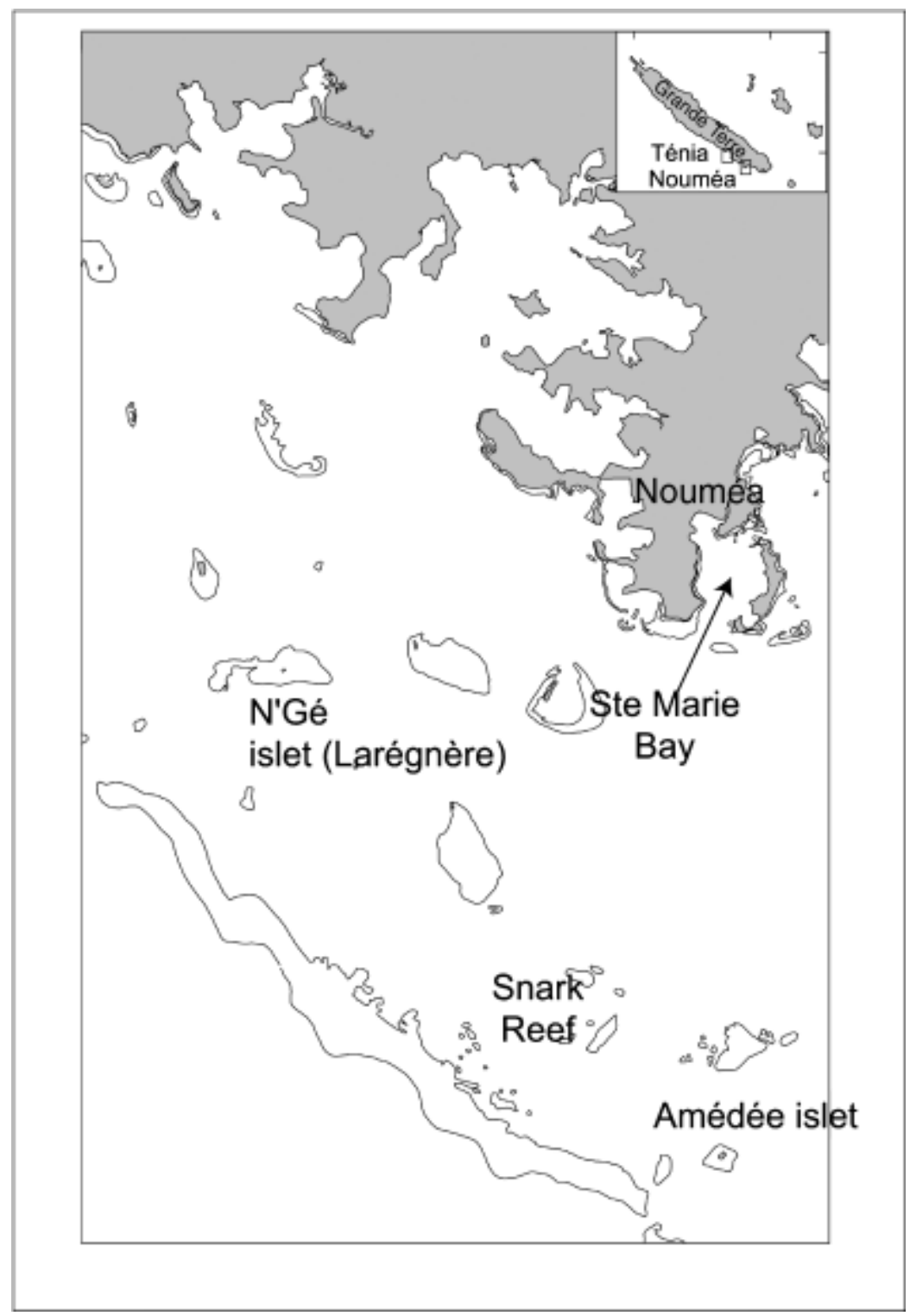

Fig. 1. Map of the sampling sites in New Caledonia 


\section{Table 1. List of samples analysed for amino acid compositions}

\section{Sample Taxonomy Location Date Depth AA-analyses}

1. OM, organic matter comprising two separate analyses, i.e. the photosynthetically active surface layer and the interior of microbialites; SOM, soluble organic matrix associated with carbonates; IOM, insoluble organic matrix associated with carbonates; DOM, dissolved organic matter in pore water associated with microbialites.

\begin{tabular}{|c|c|c|c|c|c|}
\hline & Entophysalis & Ste Marie Bay & \multicolumn{2}{|l|}{ January } & $\mathrm{OM}$ \\
\hline & Hydrocoleum & Ste Marie Bay & \multicolumn{2}{|l|}{ January } & $\mathrm{OM}$ \\
\hline 01-01-01 & P. crosbyanum & M'Bo & \multicolumn{2}{|l|}{ January } & $\mathrm{OM}$ \\
\hline 01-01-06 & P. hendersonii & M'Bo & \multicolumn{2}{|l|}{ January } & $\mathrm{OM}$ \\
\hline 01-01-09 & P. crosbyanum & M'Bo & \multicolumn{2}{|l|}{ January } & $\mathrm{OM}$ \\
\hline 01-01-13 & Phormidium sp. TK1 & M'Bo & \multicolumn{2}{|l|}{ January } & $\mathrm{OM}$ \\
\hline $02-01-51$ & Phormidium sp. TK1 & Larégnère & February & $15 \mathrm{~m}$ & OM-SOM-IOM \\
\hline $02-01-55$ & P. crosbyanum & Larégnère (C) & February & $15 \mathrm{~m}$ & OM-SOM-IOM \\
\hline \multirow{2}{*}{$03-01-21$} & P. crosbyanum & Larégnère (C) & March & $15 \mathrm{~m}$ & OM-SOM-IOM \\
\hline & P. laysanense & Snark & \multicolumn{2}{|l|}{ March } & $\mathrm{OM}$ \\
\hline 04-01-21 & P. hendersonii & Amédée & April & $12 \mathrm{~m}$ & OM-SOM-IOM \\
\hline 04-01-24 & Phormidium sp. TK1 & Amédée & April & $12 \mathrm{~m}$ & OM-SOM-IOM \\
\hline 06-01-03 & P. crosbyanum & Larégnère & June & $15 \mathrm{~m}$ & OM-SOM-IOM \\
\hline \multirow{2}{*}{ 06-01-05 } & P. crosbyanum & Larégnère & \multicolumn{2}{|l|}{ June } & DOM (pore water) \\
\hline & P. crosbyanum & Poe & December & $1 \mathrm{~m}$ & OM-SOM-IOM \\
\hline $12-01-122$ & P. hendersonii & M'Bo & December & $6 \mathrm{~m}$ & $\mathrm{OM}$ \\
\hline $12-01-129$ & P. laysanense & Snark & December & $10 \mathrm{~m}$ & $\mathrm{OM}$ \\
\hline $12-01-150$ & Entophysalis & M'Bo & December & $12 \mathrm{~m}$ & $\mathrm{OM}$ \\
\hline $12-01-208$ & P. crosbyanum & Amédée & December & $15 \mathrm{~m}$ & OM \\
\hline
\end{tabular}


Table 2. Lipophilic pigment contents in the photosynthetically active surface layer of microbialites sampled in New Caledonia in December 2001

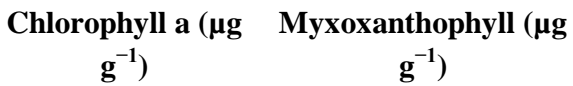

$\left.\mathrm{g}^{-1}\right)$

Phormidium crosbyanum

(Poé <1 m)

Phormidium crosbyanum

(Amadée $12 \mathrm{~m}$ )

Phormidium TK1 (Amédée

$12 \mathrm{~m}$ )

Phormidium hendersonii (Poé <1 m)

Phormidium hendersonii (M'Bo $6 \mathrm{~m}$ )

Phormidium laysanense

(Snark I-10 m)
52.4

20.3
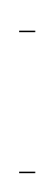

107.2
1399

530

5730

134.7

38.7

47.7

56.6

81.0

3533
Zeaxanthin ( $\mu \mathrm{g}$

$$
\left.\mathrm{g}^{-1}\right)
$$

Beta-carotene

$\left(\mu g^{-1}\right)$

Fucoxanthin ( $\mu \mathrm{g}$

$\mathrm{g}^{-1}$ ) 


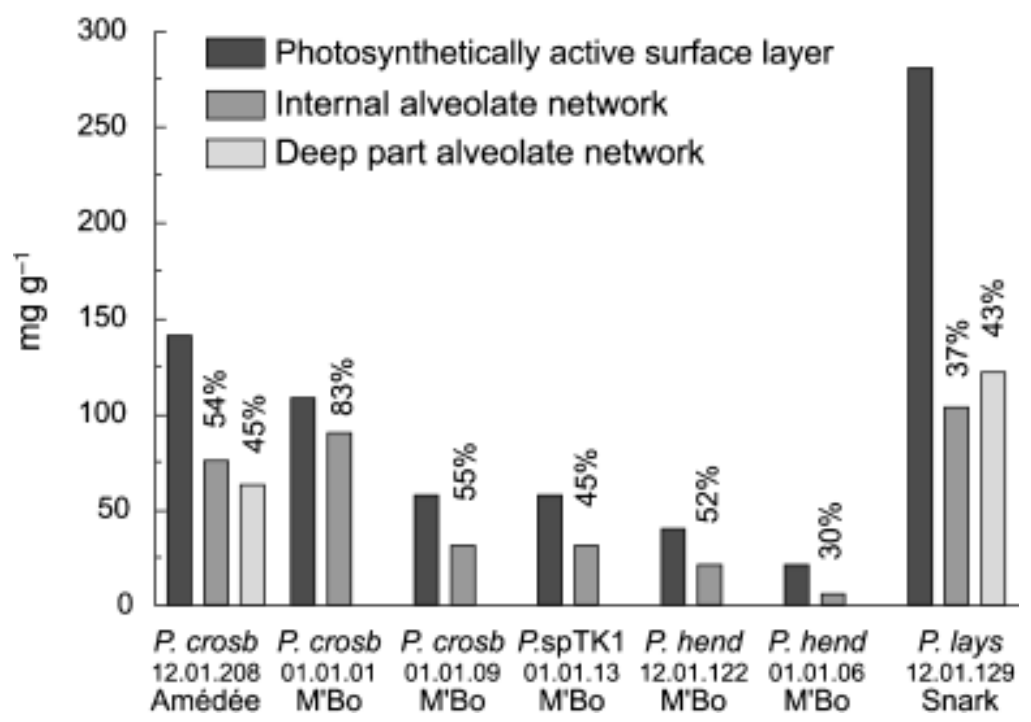

Fig. 2. Protein content of the bulk organic matter in different layers of microbialites built by the four Phormidium species. 

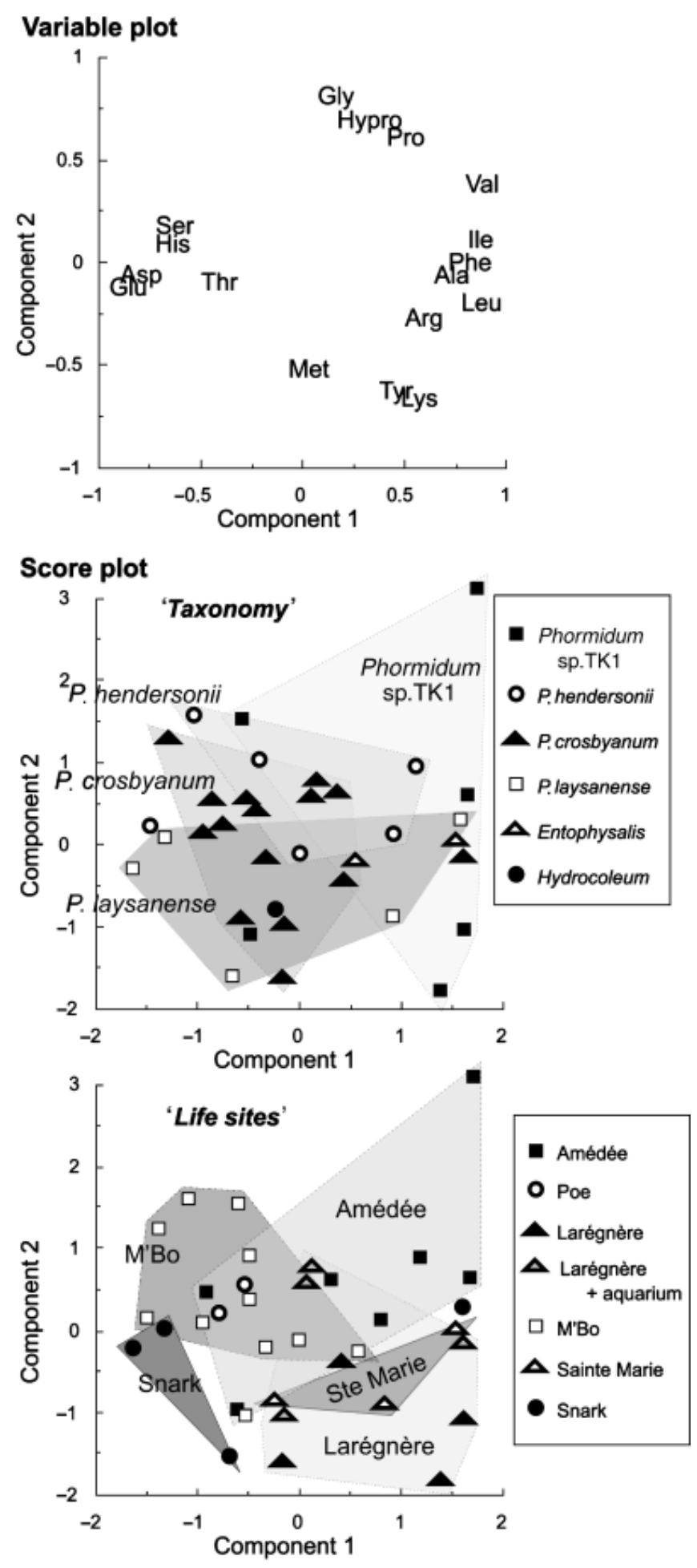

Fig. 3. Principal Component Analyses of hydrolysable amino acids (see methods) in the bulk organic matter from the photosynthetically-active surface-layer as well as from the interior alveolate organic network of New Caledonian microbialites.

Statistic conditions: 35 samples, 17 variables (amino acid contents); proportion on component 1: $40 \%$, component 2: $17 \%$ (cumul.: $57 \%$ ) 

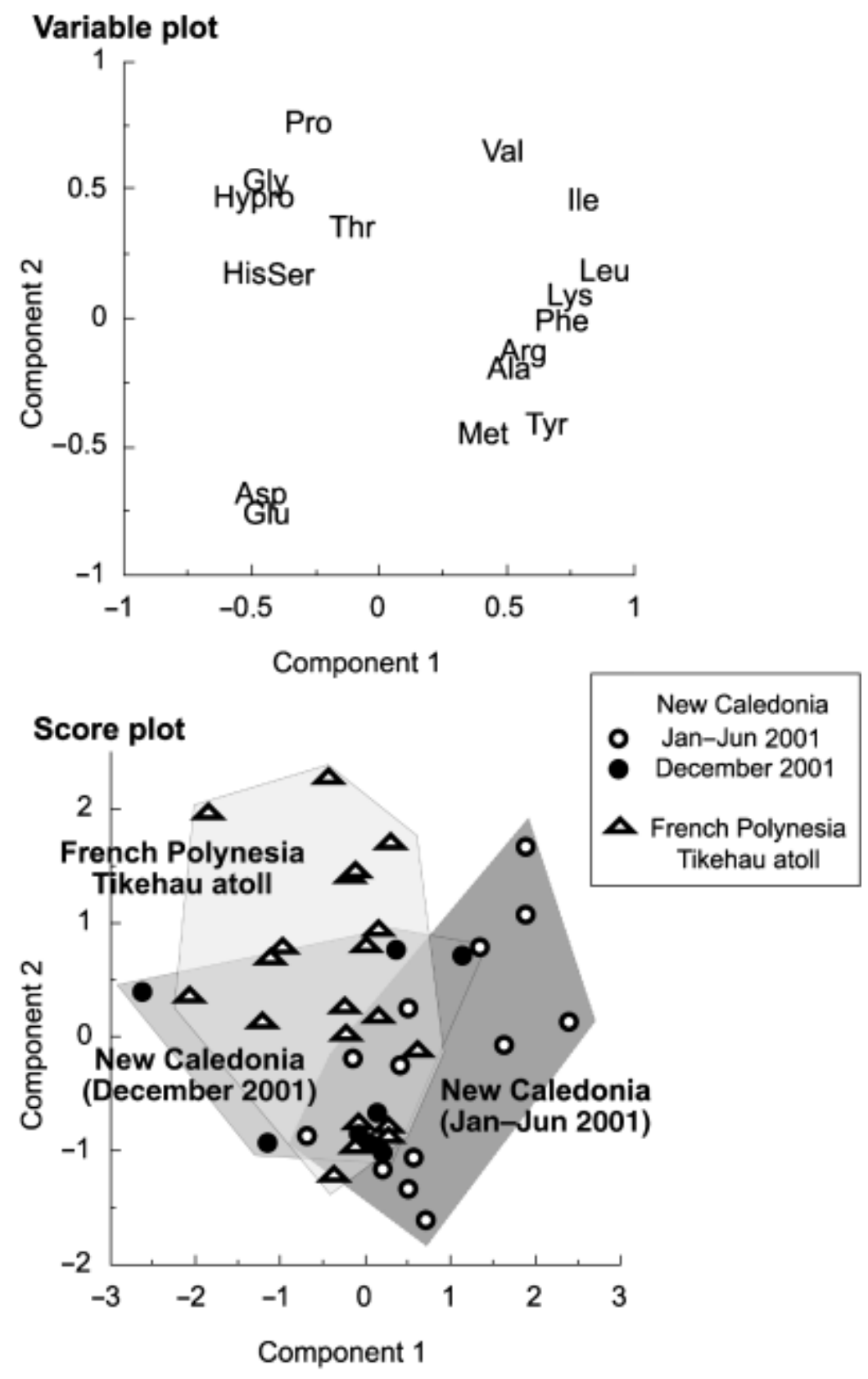

Fig. 4. Principal Component Analyses of hydrolysable amino acids (see methods) in the bulk organic material of the photosynthetically active surface layer of cyanobacteria-built microbialites sampled from both New Caledonia and Tikehau atoll (French Polynesia).

Statistic conditions: 42 samples (21 collected in Tikehau lagoon, 21 collected in New Caledonia); 17 variables (amino acid contents); proportion on component 1: $30 \%$, component 2: $20 \%$ (cumul.: 50\%) 

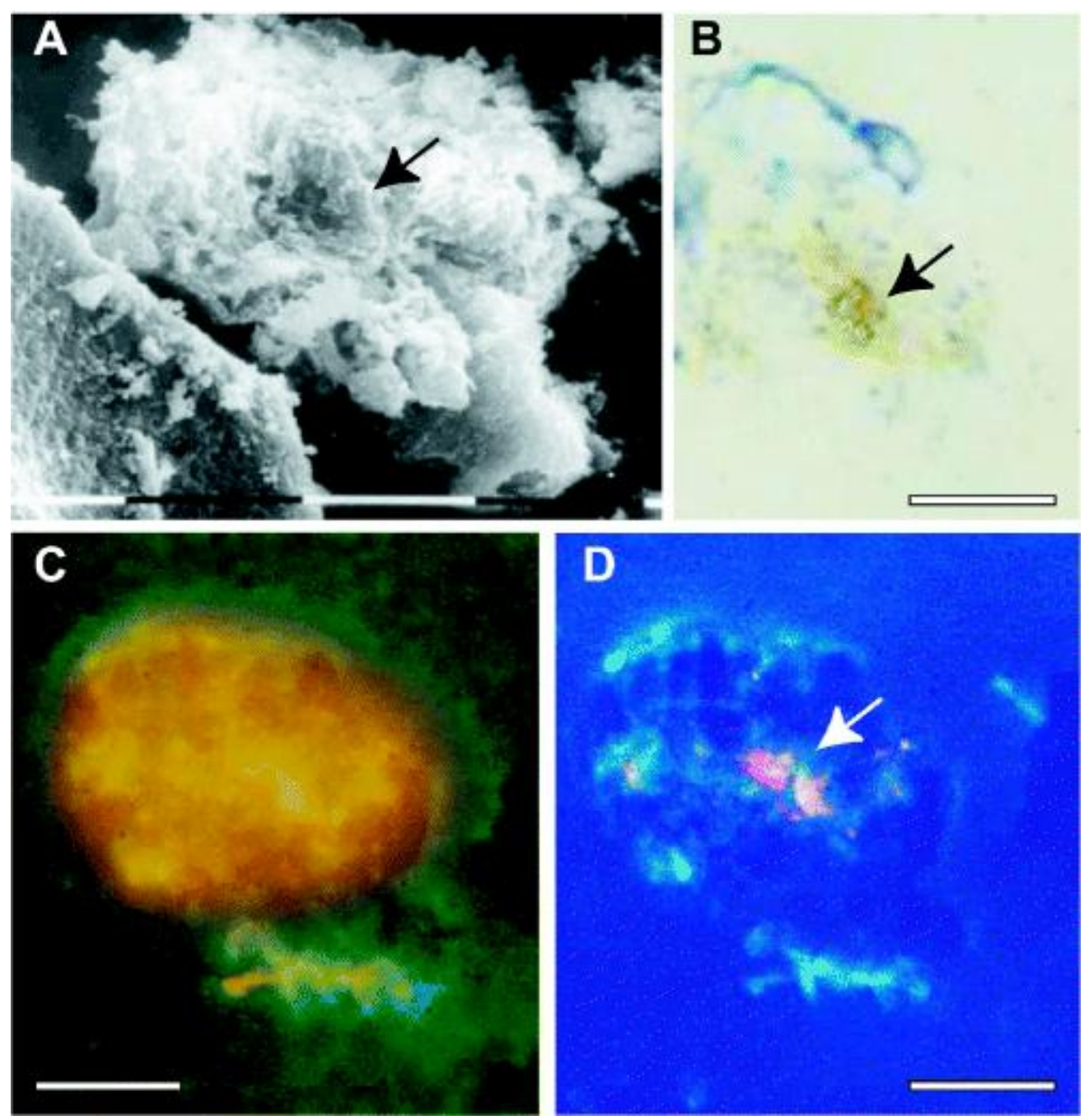

Fig. 5. Photomicrographs of extracted carbonate (see methods): broken piece of tube-forming encrustations around cyanobacterial sheaths. Arrows point to the fragment of cyanobacterial filament remaining within the carbonate tube. Scale: $10 \mu \mathrm{m}$ (segments in A).

(A) Scanning Electron Microscopy (SEM) picture. (B) Fluorescent microscopy of polished thin slab stained with non-fluorescent Aniline Blue dye, light-microscope. (C, D) Same preparation stained with fluorescent Acridine Orange. Observation under blue light (435 nm) excitation (C), under UV (365 $\mathrm{nm}$ excitation) 

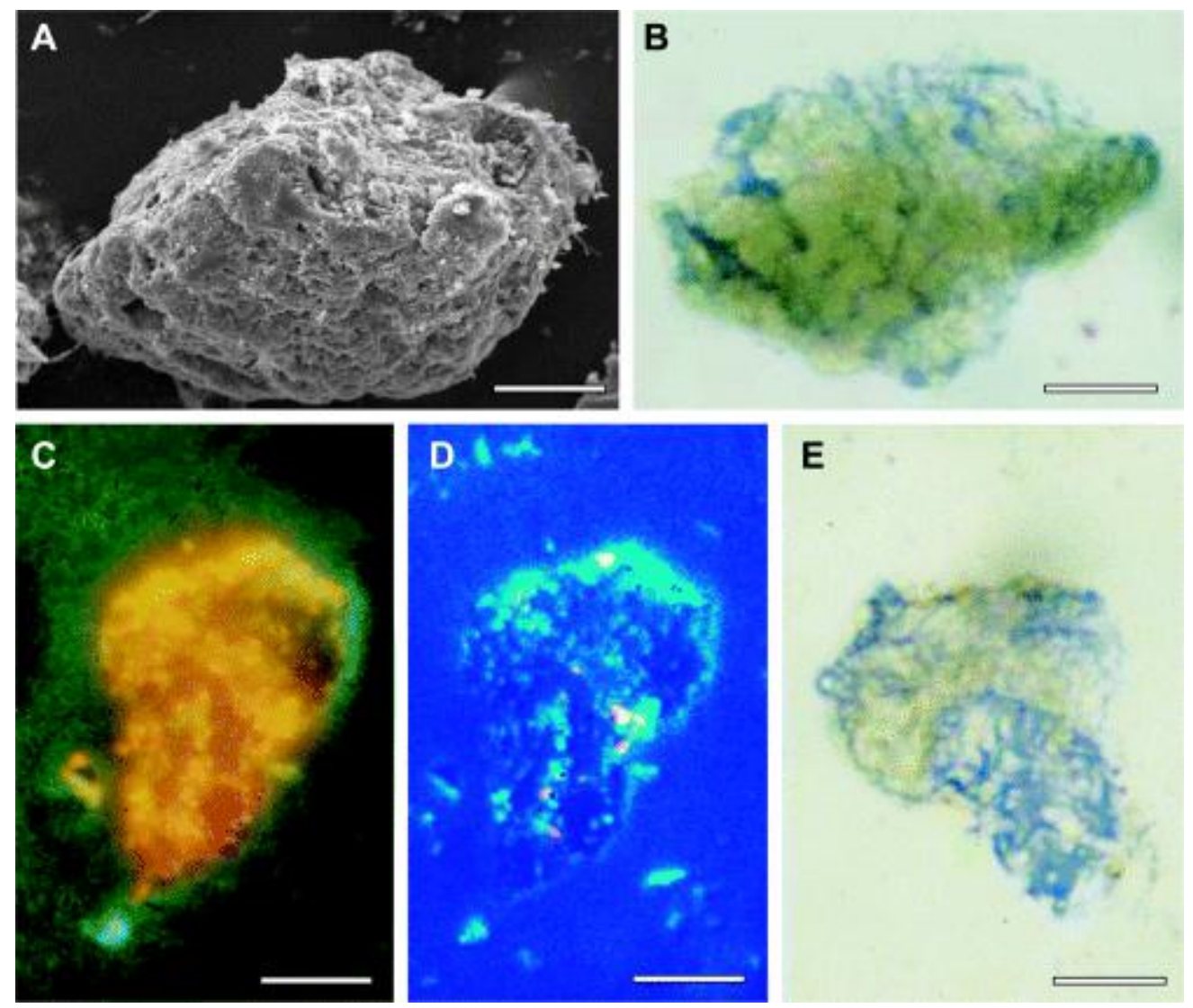

Fig. 6. Photomicrographs of extracted carbonate (see methods): micropeloid shaped grains. Scale: 10 $\mu \mathrm{m}$.

(A) Scanning Electron Microscopy (SEM) picture. (B) Aniline blue-stained thin section oberved under the optical light microscope. (C, D) Fluorescent acridine organge staining: observation under blue light (435 nm) excitation (C), under UV (365 nm excitation). (B) Aniline blue-staining of the same grain. 

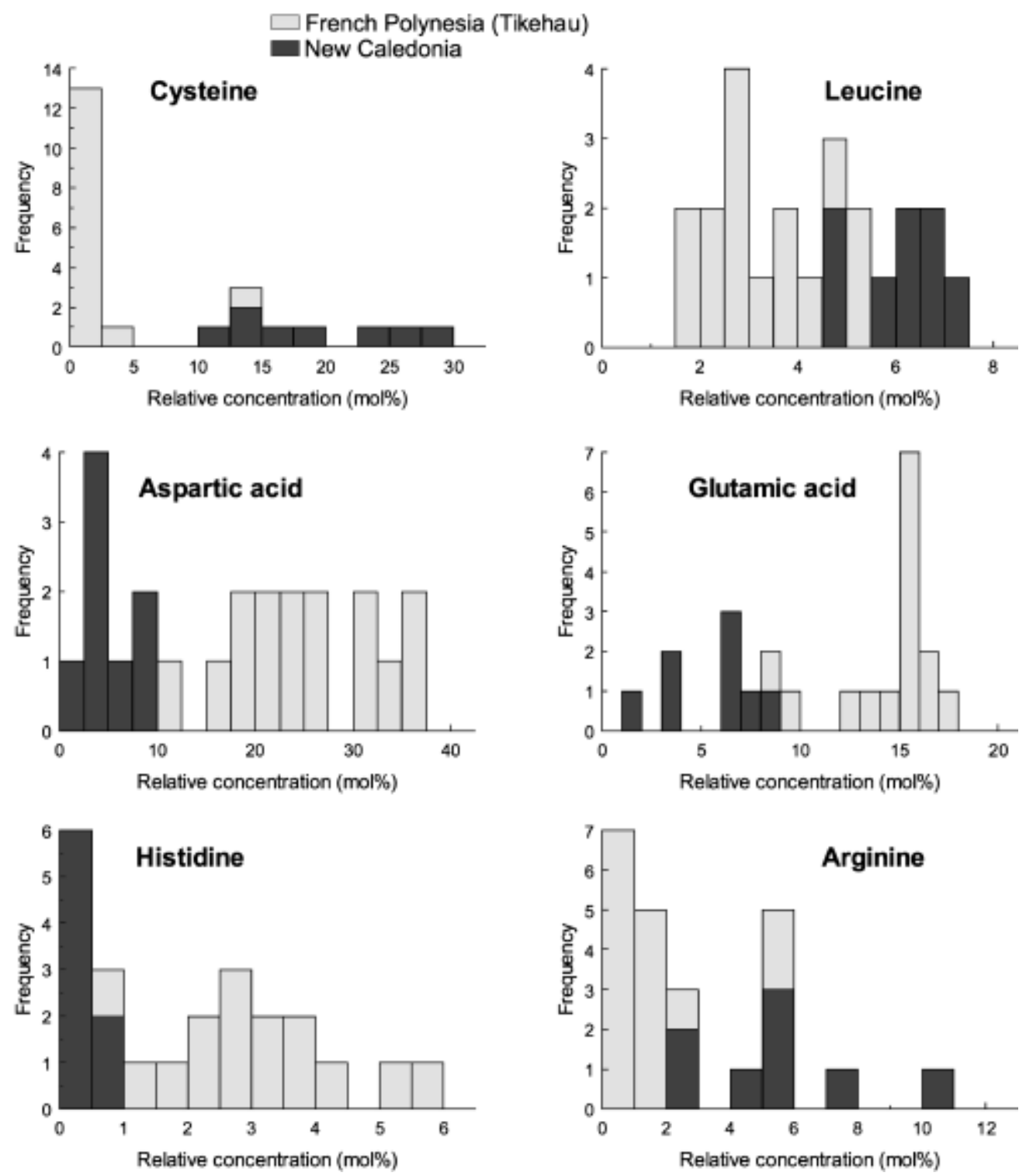

Fig. 7. Frequency histograms of the content of selected amino acids expressed as a molar percentage of the total hydrolysable amino acid pool for the soluble organic matrices (SOM) associated with in-situ precipitated carbonates 

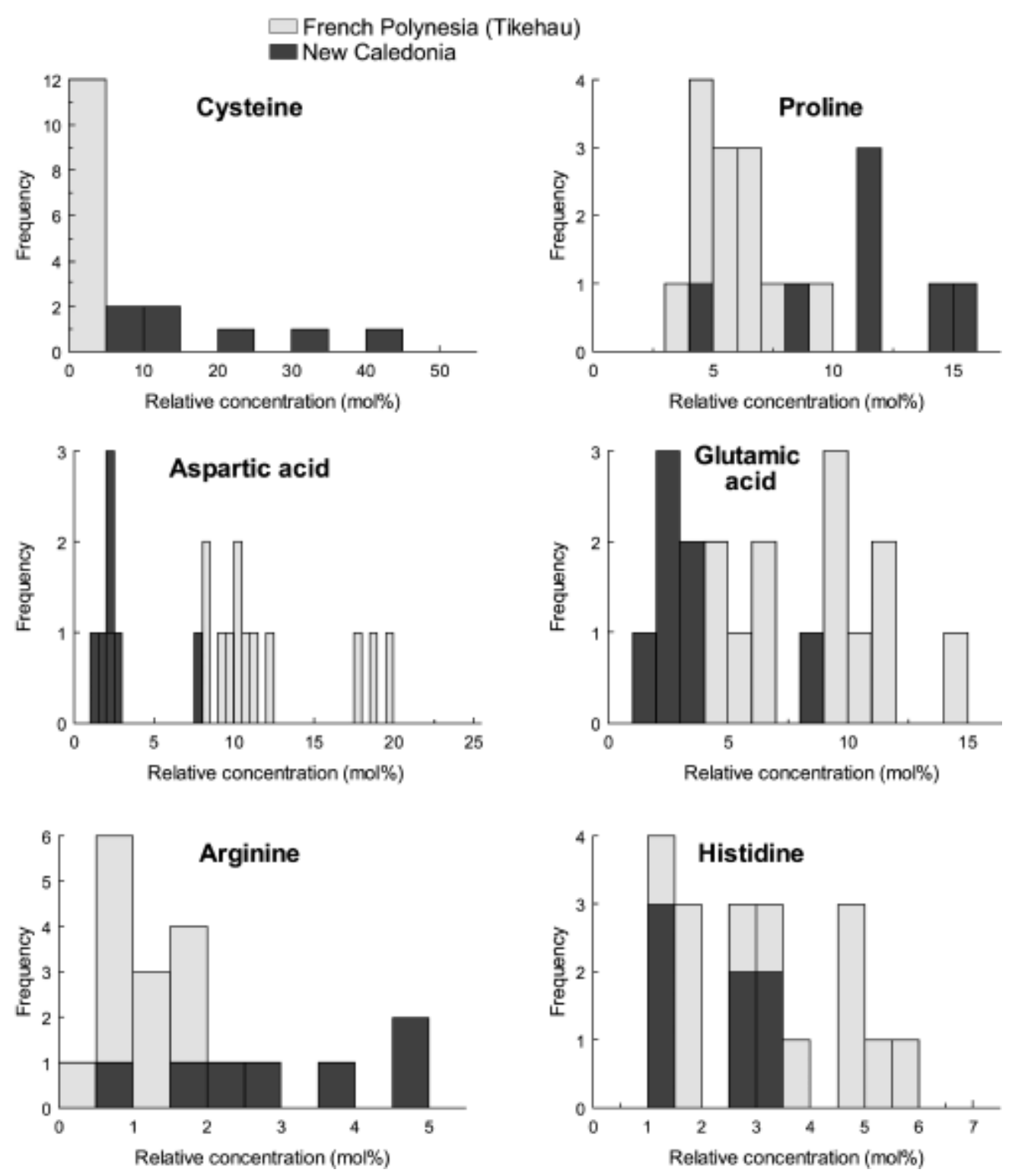

Figure 8. Frequency histograms of the content of selected hydrolysable amino acids (see Methods) expressed as a molar percentage of the total hydrolysable amino acid pool for the soluble organic matrices (SOM) and insoluble organic matrices (IOM) associated with in situ precipitated carbonates. 

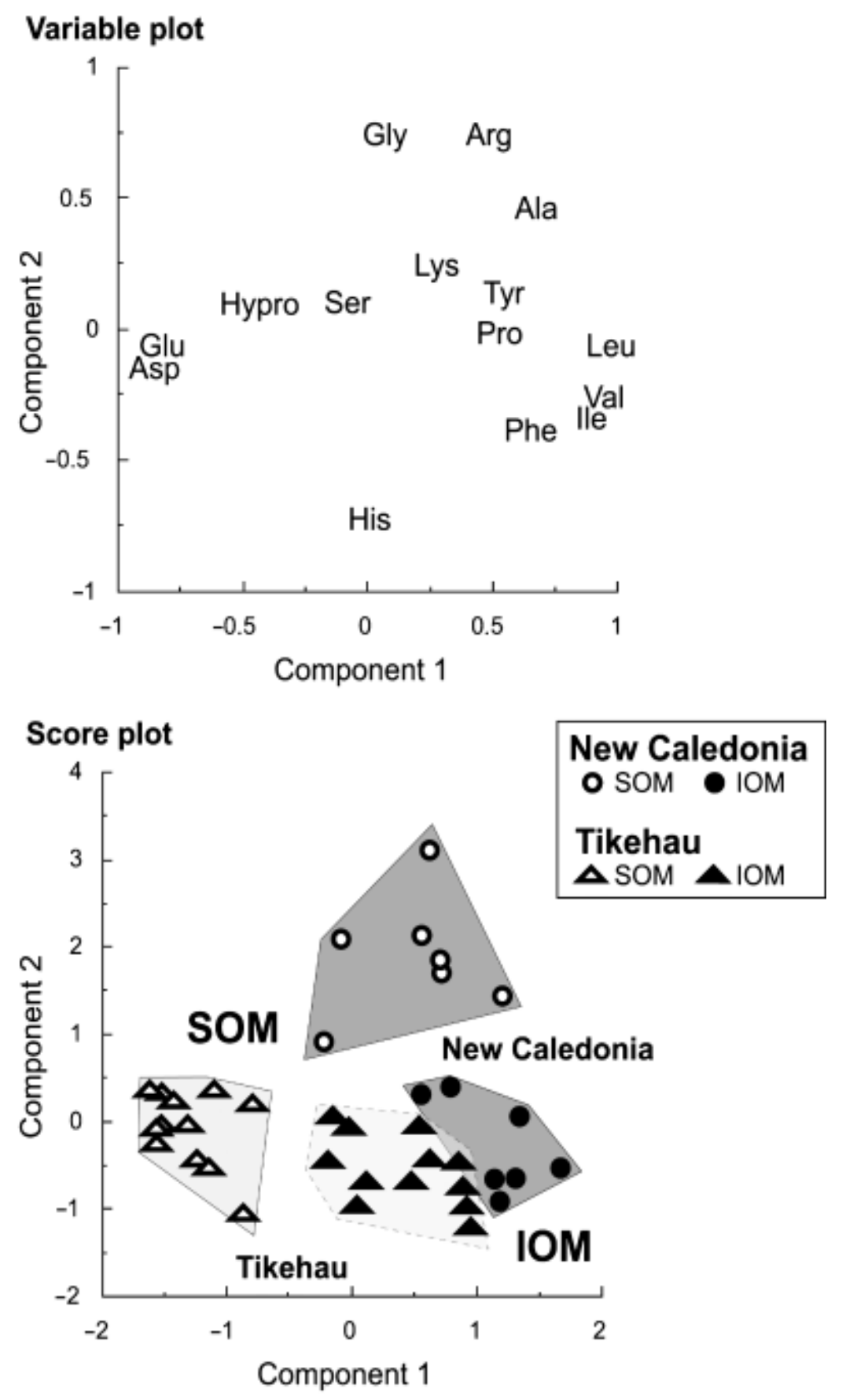

Figure 9. Principal component analyses of relative proportions of hydrolysable AA (cysteine excluded) of the organic matrices associated with in situ precipitated carbonates (SOM, soluble organic matrix; IOM, insoluble organic matrix). 
Table 4. Metal concentrations (ICP-AES) obtained in three microbialites domes from two areas of the Nouméa lagoon, and built by two distinctive species. The metal concentrations are compared with the results obtained on a certified sample

$$
\begin{array}{lllll}
\text { Cr (p.p.m) } & \text { Cu (p.p.m) } & \text { Ni (p.p.m) } & \text { Pb (p.p.m) } & \text { Zn (p.p.m) }
\end{array}
$$

P. crosbyanum, Tabu Reef (sample 01-01-26)

\section{Anal 1}

15

Anal 2

15

Phormidium sp. TK1, M'Bo (sample 03-01-04)

\section{5}

23

Anal 2

P. crosbyanum, M'Bo (sample 12-01-206)
Standard (CRM, LGC 6137)

$$
\text { Certified values }
$$

Anal 2 $\leq 10$ 


\section{Photosynthetically active surface layer}

AA composition changed during year 2001 and resembled Polynesian counterpart only in December

Diatoms + fucoxanthin

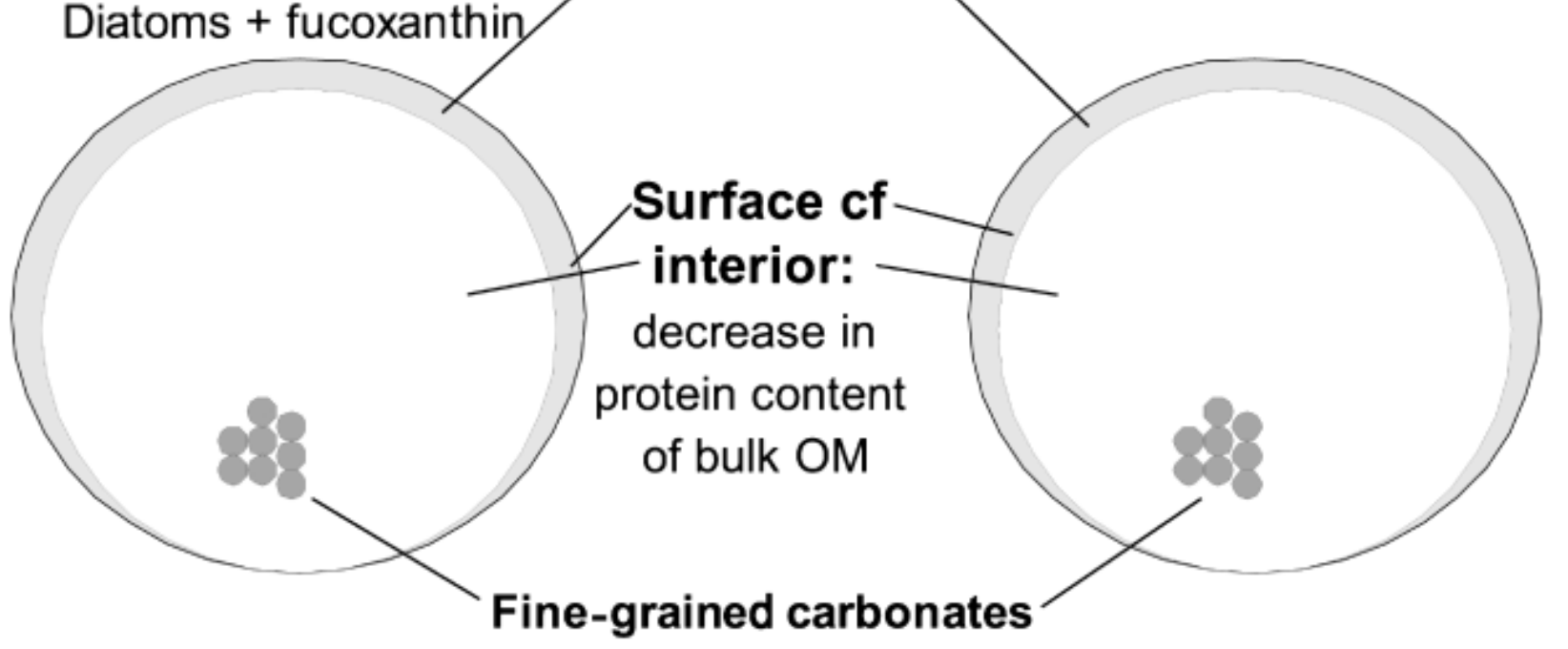

Intramineral matrices very rich in Cys, rich in Leu, Ala and Arg, and low in His
AA composition dominated by Gly, Ala, Leu, Val Asp, Glu Intramineral matrices very rich in Asp and Glu Cys low or n.d.

Fig. 10. Schematic representation of the common characters and differences between Phormidiumbuilt microbialites from the lagoons of Tikehau (French Polynesia) and Nouméa (New Caledonia) 